\section{Kirurgisk kompendium som app}

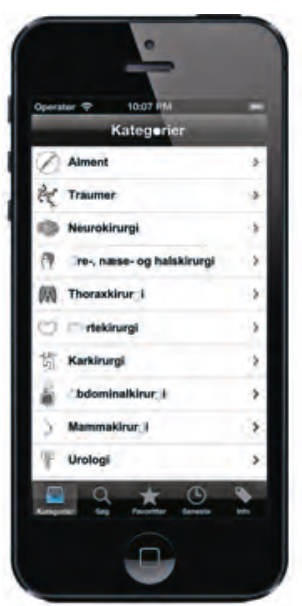

Lars Bo Svendsen, Jørgen Nordling,

Benny Dahl et al.

Kirurgisk Kompendium Kittelbog som app

App til iPhone, iPad og iPod Touch. 17.2 MB.

København: Nyt Nordisk Forlag, 2012.

Språk: dansk og engelsk. Pris NOK 420

www.medicinskkompendium.dk

De fleste kirurger som har sitt virke i Skandinavia, kjenner til det danske storverket Kirurgisk kompendium, og de fleste av disse igjen setter det svært høyt. Gjennom høy faglig standard og ikke minst en pedagogisk og oversiktlig tilnærming til stoffet har denne boken vært et selvsagt innslag på kirurgkontorene rundt om i landet.

Som enhver lærebok innen medisinfaget vil et slikt verk naturlig nok bli ganske omfangsrikt. Selv for den mest dedikerte unge kirurg vil den ikke kunne la seg frakte rundt i frakkelommen. For å bøte på dette har man nå i flere år utgitt en komprimert utgave kalt en kittelbok.

Tredje utgave foreligger nå, og i takt med tidens utvikling har man denne gangen også gjort den tilgjengelig som app for iPhone og iPad.

Første gang jeg kom over kittelutgaven av Kirurgisk kompendium, var tidlig i min kirurgkarriere. Den gang, som senere, var den til uvurderlig hjelp for et forvirret hode. Da boken etter hvert måtte kasseres, var det ikke på grunn av misnøye med innholdet, men rett og slett grunnet slitasje. Når jeg nå igjen har gått gjennom boken med et forhåpentligvis noe mindre forvirret hode, er det med stor glede jeg kan konkludere med at den ikke bare har opprettholdt sin høye standard, den har også forbedret den.

Boken starter med et allment kapittel som omhandler generelle kirurgiske emner og problemstillinger. Alt fra den preoperative vurdering til valg av suturer dekkes lettleselig og med høy faglig kva-

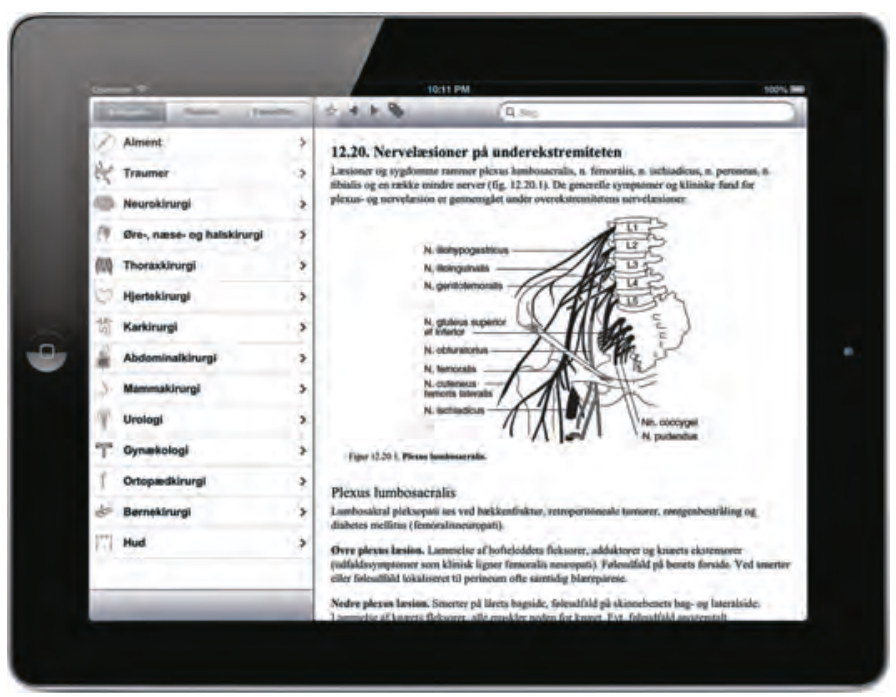

litet. Det generelle kapitlet følges av et om traumatologi. Dette er et av feltene som for den unge kirurg fremstår som både det mest spennende og ikke minst skremmende. Forfatterne gir en god oversikt over mottak og initial behandling av traumepasienter. Siden også Danmark baserer sitt traumesystem på ATLS (Advanced trauma life support), er de prinsippene som fremkommer, direkte overførbare til vår hjemlige situasjon. I tillegg til den initiale vurderingen av den skadede pasienten går forfatterne i egne underkapitler grundig igjennom evaluering av de forskjellige organsystemene. Det eneste jeg kunne $\emptyset$ nske meg var tatt med, var et eget kapittel om prinsippene bak skadebegrensende kirurgi (Damage control surgery).

Boken er også grundig oppdatert siden forrige utgave når det gjelder områder som minimal invasiv kirurgi og utredning av kreftsykdommer.

Etter disse to mer generelle emnene går forfatterne videre med kapitler om de ulike kirurgiske spesialitetene og subspesialitetene. De dekker her alt fra de tradisjonelle bløtdelskirurgiske subfagene som gastrokirurgi, urologi og karkirurgi, til ortopedi, gynekologi og øre-nese-hals-sykdommer. Hvert kapittel begynner også her med en generell oversikt over de viktigste prinsippene innenfor hvert organområde. Disse organkapitlene gir en svært god og lettfattelig oversikt over den store majoriteten av kirurgiske diagnoser og problemstillinger man kommer over i en klinisk hverdag. Man får en god gjennomgang av symptomer og funn, i tillegg til anbefalte tilleggsunders $\varnothing$ kelser og behandling.

Fungerer så en slik bok også som app? Svaret må bli et klart ja, oppbyggingen er som skapt for appformatet. Det som gjør den oversiktlig i papirutgaven, blir enda tydeligere når man kan navigere ved hjelp av fingertuppene. Man hopper lett frem og tilbake mellom de ulike emnene, og kapitlene har beskrivende overskrifter som gjør det lett å finne rett emneside. I tillegg kan man enkelt legge inn favoritter i en egen liste, slik at man raskt finner tilbake til dem. Søkefunksjonen fungerer stort sett greit, men er begrenset til søk i kapitteloverskriftene. Det ville vært en fordel med mulighet for mer omfattende tekstsøk.

Et annet negativt poeng er manglende mulighet til å legge inn egne notater. En slik funksjon ville vært til stor nytte og burde vært en selvfølge i en medisinsk app av denne typen.

Appen er kun tilgjengelig for iPhone/iPad, noe som nok vil falle de mange Android-brukerne tungt for brystet. Det er vanskelig å forstå hvorfor man ikke samtidig har utviklet en versjon for dette markedet, men vi får håpe det rettes opp i fremtiden.

På faglig grunnlag anbefaler jeg Kirurgisk kompendium kittelbog som app på det sterkeste, men den har altså noen minuser når det gjelder det rent tekniske. Noen vil nok også synes at prisen på 420 norske kroner er i stiveste laget. Med dagens smarttelefonteknologi finnes det tross alt en del gratis alternativer. Er man flink til å bruke Google og mer spesialisert medisinsk søkeverktøy, er man bare noen få tastetrykk unna den samme informasjonen som man får i boken. Blant annet kan man gjennom Helsebiblioteket.no få full tilgang til det medisinske nettstedet UpToDate som vil kunne gi vel så god informasjon om de fleste kirurgiske problemstillinger.

Men velger man å bruke disse kronene, er jeg ganske sikker på at man ikke vil angre. Appen passer svært godt for turnusleger og kirurger tidlig i sin spesialisering og vil nok også kunne være et godt hjelpemiddel for erfarne kirurger som går generelle kirurgiske foreller bakvakter. Medisinstudenter vil også ha stor nytte av appen både i praksistiden og ved eksamensforberedelser.

\section{Sturla Pilskog}

Kirurgisk klinikk

Haraldsplass diakonale sykehus Bergen 